DOI: $10.14746 /$ por.2018.1.13

\title{
"STRACH" W KOMEDII NIKOŁAJA RUDKOWSKIEGO DOŻYĆ DO PREMIERY I JEJ TŁUMACZENIU NA JĘZYK POLSKI
}

\author{
Natalia Rusiecka ${ }^{1}$ \\ (Uniwersytet Marii Curie-Skłodowskiej w Lublinie)
}

\begin{abstract}
Słowa kluczowe: emocje, strach, białoruska dramaturgia rosyjskojęzyczna Key words: emotions, fear, Belarusian dramaturgy in Russian
\end{abstract}

\begin{abstract}
Abstrakt: Natalia Rusiecka, „STRACH” W KOMEDII NIKOŁAJA RUDKOWSKIEGO DOŻYĆ DO PREMIERY I JEJ TŁUMACZENIU NA JĘZYK POLSKI. „PORÓWNANIA” 1 (22), 2018. T. XXII, S. 237-247. ISSN 1733-165X. W niniejszym artykule została podjęta próba analizy wybranych językowych wykładników emocji strachu w komedii Dożyć do premiery napisanej w języku rosyjskim przez współczesnego dramatopisarza białoruskiego Nikołaja Rudkowskiego oraz w polskim przekładzie tej sztuki autorstwa Bożeny Majorczyk. Zwraca się uwagę na to, iż mimo podobieństwa „skryptów kulturowych" i doświadczeń historycznych są istotne różnice w rozumieniu tekstu pomiędzy odbiorcą przynależącym do rosyjskojęzycznego oraz do polskojęzycznego kręgu kulturowego.
\end{abstract}

\begin{abstract}
Natalia Rusiecka, THE CONCEPT OF FEAR IN NIKOLAY RUDKOVSKI'S COMEDY „TO LIVE TO SEE THE OPENING NIGHT” AND IN THE TRANSLATIONS OF THE COMEDY INTO POLISH. "PORÓWNANIA" 1 (22), 2018. Vol. XXII, P. 237-247. ISSN 1733-165X. This article attempts to analyze selected language exponents of the emotion of fear in the comedy "To Live to See the Opening Night". This play was written in Russian by the contemporary Belarusian playwright Nikolay Rudkovski and translated into Polish by Bożena Majorczyk. Attention is drawn to the fact that, despite the similarity of "cultural scripts" and historical experiences, there are significant differences in the perception of the text between the recipients belonging to the Russian-speaking and the Polish-speaking cultural circle.
\end{abstract}

1 E-mail: nata.rusiecka@gmail.com 
Zagadnienie emocji interesuje zarówno naukowców z różnych dziedzin: psychologów, językoznawców, filozofów i innych, jak i zwykłych ludzi. Jeden z pierwszych badaczy emocji Paul Ekman podał w 1972 roku listę sześciu podstawowych emocji, za które uznał: gniew, zaskoczenie, odrazę, strach, szczęście i smutek. Później lista była poszerzana albo skracana i obejmowała - w zależności od teorii - od trzech do jedenastu pozycji, jednak strach zawsze był wymieniany wśród podstawowych emocji. Ostatnio coraz częściej naukowcy analizują koncept strachu w obrębie jednego języka lub porównując dane z kilku języków (zob. Oparina; Małecki; Krasavskij).

W niniejszym artykule została podjęta próba analizy wybranych językowych wykładników emocji strachu w oryginale i w polskim przekładzie komedii Nikołaja Rudkowskiego Dożyć do premiery. Za punkt wyjścia posłużył strach, który przeżywają bohaterowie sztuki, zanalizowano sposoby nazywania i wyrażania go w wersji oryginalnej i tłumaczonej z uwzględnieniem różnic językowych i kulturowych, które w założeniu Anny Wierzbickiej utrwalone są w podświadomości za pomocą „skryptów kulturowych" (Wierzbicka 189).

Nikołaj Rudkowski (ur. 1971) to rosyjskojęzyczny dramatopisarz białoruski, autor kilkunastu utworów wystawianych w teatrach Białorusi, Rosji, Ukrainy, Polski oraz innych krajów europejskich, prowadzi audycje radiowe w białorusko-niemieckiej rozgłośni Unistar, jest koordynatorem białoruskiego komitetu europejskiej sieci promującej tłumaczenia dramatów „Eurodram”. Jego utwory są publikowane na łamach rosyjskiego czasopisma "Sowriemiennaja dramaturgija”, w wydaniach zbiorowych, ukazujących się w Rosji, Białorusi, Polsce, Francji, zarówno w oryginalnej wersji językowej, jak i w tłumaczeniach.

Tekst omawianej w artykule sztuki Rudkowskiego podejmuje temat II wojny światowej. Główna bohaterka, aktorka Wiera dostaje rolę partyzantki w przygotowywanym $\mathrm{w}$ teatrze spektaklu. Mimo że jest to niewielka drugoplanowa rola, podchodzi do niej poważnie i, stosując metodę Stanisławskiego, chce doświadczyć tych emocji, które towarzyszyły ludziom podczas wojny. Przede wszystkim chce odczuć strach: strach przed bólem, głodem, utratą bliskich, własną śmiercią. Sprawdzić, czy jest na tyle mocna, żeby to wszystko wytrzymać. Wciąga w swoje doświadczenia męża, koleżankę (również aktorkę) Katię, instruktora fitnessu. Trudno jednoznacznie wywnioskować z tekstu, czy bohaterce udaje się osobiście przeżyć to, do czego dąży, warto jednak prześledzić, jakie sytuacje modeluje Wiera, żeby odczuć strach, jakie jednostki językowe przekazują tę emocję w tekście oryginału i tłumaczenia.

W swoim dążeniu do przeżycia prawdziwego strachu aktorka szuka coraz mocniejszych bodźców, o czym mówi już na samym początku. Rozmawia też o strachu z innymi bohaterami sztuki, żeby zrozumieć, czego boi się współczesny człowiek. Zamierzeniem Wiery jest poczuć strach, żeby pokonać go w sobie i odważyć się na czyn bohaterski. Wszystko po to, by wiedzieć, jak zagrać go w spektaklu. Próbuje 
więc odtworzyć warunki wojennej rzeczywistości w swoim życiu: zasłania w domu okna (jak przed bombardowaniem), odcina telefon, biega na siłowni przy ścieżce dźwiękowej ze szczekaniem psów, gotuje w domu ziemniaki w mundurkach i zupę z pokrzywy, wymienia kosztowności na chleb. Proponuje koleżance Katii przenieść się do pokoju rodziców, a drzwi do własnego pokoju zabarykadować szafą, jakby ukrywała w nim rodzinę żydowską. Katia nie zgadza się, lecz Wiera nalega, mówiąc, że w dzieciństwie pewnie lubiła wejść do łóżka rodziców. Koleżanka wspomina, jak to było i mówi:

Катя. Так это в детстве. Ночью страшно было.

Вера. А на войне не страшно?

Катя. Ещё не знаю (Rudkovskij 2016: 528).

Strach został $\mathrm{w}$ tym dialogu wyrażony eksplicytnie za pomocą leksemu страшно, które $\mathrm{w}$ tekście rosyjskim ma wyraźną podmiotowość: to Katia czuła strach, kiedy była mała, i nie wie, czy to samo czuje się na wojnie. Niestety w tłumaczeniu poprzez wykorzystanie niewłaściwej dla języka polskiego konstrukcji strach staje się bezosobowy, a nawet wszechogarniający.

KATIA Wtedy byłam malutka. Nocą było jakoś strasznie...

WIERA A w czasie wojny nie jest strasznie?

KATIA Jeszcze nie wiem (Rudkowski 2014: 94).

Aktorki pragną dowiedzieć się, jak jest na wojnie, oraz doświadczyć prawdziwych emocji: Wiera wpada na pomysł, żeby razem z koleżanką wynieść ze sklepu jakiś towar (w rzeczywistości - po prostu go ukraść). Może wtedy uda się poczuć, co przeżywała jej babcia, która wynosiła na sobie miny z okupowanej wsi. Ekspedientka przyłapuje dziewczyny na gorącym uczynku, a wtedy Katia zaczyna recytować monologi z Czechowa, dezorientując swoim zachowaniem pracownicę sklepu, po czym wyznaje koleżance, że nie czuła strachu:

Катя. А ты знаешь, Вера, страшно по-настоящему мне не было. Мы сыграли, а хотелось чего-то другого.

Вера. Да, нам нужен настоящий страх. Обыска, голода, холода, смерти (Rudkovskij 2016: 546).

Warto zwrócić uwagę, że w tym fragmencie w kwestii Katii znów zostaje użyte słowo страшно, jednak tym razem tłumacz wykorzystuje bardziej charakterystyczną dla języka polskiego, osobową formę wyrażenia tego uczucia. Natomiast w kwestii Wiery "strachu” na poziomie leksykalnym jest trzy razy więcej: 
KATIA Wiesz co, Wiera... tak naprawdę wcale się nie bałam... wiedziałam, że gramy, a czułam, że pragnę czegoś zupełnie innego.

WIERA Niewątpliwie tak... musimy zaznać uczucia prawdziwego strachu. Strachu przed rewizją, głodem, zimnem, strachu przed śmiercią (Rudkowski 2014: 112-113).

Niestety, aktorki raz za razem przeżywają rozczarowanie, bo nie czują autentycznego strachu, wiedząc, że ich postępowanie to tylko gra, dekoracje. Dziewczyny jednak nie poddają się i próbują szukać innych możliwości, żeby przeżyć „prawdziwy strach". W dalszej części dialogu Katia zastanawia się, co można zrobić, żeby wreszcie poczuć realne emocje. Wiera w tym czasie ma już kolejną propozycję:

Катя. Если бы это были мужики в форме, то, может, мы бы испугались. Да?

Вера. Мы найдем таких. У меня есть один экземпляр. Наша новая цель - успешно пройти пытки. Мы должны выдержать, и мы ничего не должны рассказать врагу, как бы мучительно больно нам ни было.

Катя. Мамочки-и-и-и (Rudkovskij 2016: 546).

KATIA Gdyby to byli faceci w mundurach, to wtedy, być może, byśmy się przestraszyły. Jak ci się wydaje?

WIERA Znajdziemy takich. Jednego już znam. Nasz nowy cel - przetrwać tortury. Musimy wytrzymać i nie mamy prawa cokolwiek wydać wrogom, bez względu na to, na jakie męki będziemy narażone.

KATIA Ra-a-tu-u-nk-u-u... (Rudkowski 2014: 113)

Katia jeszcze nie wie, co ją czeka, nie wie, jak będzie się zachowywać w sytuacji, kiedy będzie musiała przeżywać tortury, więc boi się. Strach został tu wyrażony w ostatniej kwestii eksplicytnie, za pomocą wołania, które w oryginale brzmi Мамочкu (pol. 'mamusiu', 'mamuniu'). W tym wyrazie jest teoretycznie wyrażony konkretny adresat, ale nie ma w semantyce tego słowa prośby o ratunek. Jest to bardzo osobiste i głęboko wewnętrzne przeżycie strachu przed bólem, przed niewiadomym. Oprócz tego replika Katii może wywołać u odbiorcy oryginału szereg skojarzeń własnych oraz wpisanych w ogólny kontekst kulturowy: na przykład, w popularnym radzieckim serialu 17 mgnień wiosny radiotelegrafistka Kathrin (nawet imiona bohaterek są podobne), która jest radzieckim szpiegiem, w momencie, kiedy rodzi dziecko, też krzyczy „mamo”, czym demaskuje siebie i wpada w ręce Gestapo.

Wróćmy jednak do pomysłu Wiery: umówiła się ona z instruktorem fitnessu na sadystyczny seans, w którym on będzie gestapowcem, torturującym partyzantki w celu wydobycia informacji o ukrywających się Żydach. Instruktor znęca się nad dziewczynami, one dzielnie wszystko znoszą, i nagle role się odwracają. Instruktor, nie wytrzymując napięcia, krzyczy: 
Фашистки! [...]Что вы меня мучаете, садистки? Уходите! Не надо! Не надо! (Rudkovskij 2016: 554).

Faszystki! [...] Co mnie tak męczycie, sadystki? Spadajcie stąd! Przestańcie! Przestańcie! (Rudkowski 2014: 121).

W replice instruktora emocja strachu nie została nazwana wprost, lecz wyrażona za pomocą środków składniowo-leksykalnych: osoba mówiąca krzyczy i błaga. W wypowiedzi wykorzystane są też nacechowane nazwy ludzi: faszystki, sadystki, wyrazy te w obu językach - rosyjskim i polskim - mają podobną konotację i nie sprawiają tłumaczowi żadnych trudności. Nieco inaczej wygląda prośba mówiącego - w oryginale yxodume, które w tłumaczeniu nabiera nieoczekiwanie i chyba niepotrzebnie odcienia groźby spadajcie stąd. Dalej chłopak wyznaje, że nie może torturować „swoich”, bo też jest Rosjaninem, a po stronie ojca ma w rodzinie również Żydów. Aktorkom znów nie udało się odczuć prawdziwego strachu, a nawet fizyczny ból okazał się znośny.

W międzyczasie Wiera wymyśla dla siebie jeszcze jedno doświadczenie. Oblewa się wodą i wychodzi na balkon. Kiedy mąż, wróciwszy z pracy, zastaje ją mokrą i zziębniętą, pyta, co się stało.

Вера. Чтобы узнать, что чувствовала Зоя Космодемьянская, когда замерзала... Это так ужасно (Rudkovskij 2016: 547).

WIERA Chciałam się przekonać, co czuła Zoja Kosmodemjańska, jak zamarzała... To takie straszne (Rudkowski 2014: 113-114).

W oryginale uczucie strachu zostało wyrażone za pomocą słowa yжасно: mówi się tak o ciężkim stanie wywołanym czymkolwiek, w danym kontekście strachem i bólem. Natomiast w polskim tłumaczeniu mamy wyraz straszne, mający mniejsze natężenie emocjonalne niż przerażające.

Warto zaznaczyć na marginesie, że tłumaczka wykorzystuje przypis, w którym tłumaczy, kim jest Zoja Kosmodemjanskaja, co pokazuje, iż postać ta jest zupełnie polskiemu czytelnikowi nieznana. Natomiast odbiorca z rosyjskiego (radzieckiego) kręgu kulturowego bardzo łatwo przywołuje szereg skojarzeń związanych ze wspomnianą bohaterką, która podczas wykonania zadania została schwytana przez Niemców i była torturowana: godzinami trzymano ją prawie gołą na mrozie i śniegu. Znana jest też wygłoszona przed straceniem mowa Kosmodemjańskiej, w której zabrzmiało słynne: „Wszystkich nie powiesicie, nas 170 milionów!”. Zresztą, pojawienie się w komedii Rudkowskiego koktajlu Mołotowa też jest w dużym stopniu odwołaniem do postaci Zoi Kosmodemjańskiej, która, będąc uzbrojona wyłącznie w butelki z mieszanką wybuchową, miała podpalać wioski, gdzie stacjonowały wojska niemieckie. Jej obraz był często wykorzystywany w sztuce: w literaturze, kinie, 
malarstwie oraz muzyce. Na długie lata stała się ona dla narodu sowieckiego przykładem bohaterstwa i patriotyzmu, jak Joanna d'Arc dla Francuzów. Tego ogromu skojarzeń, gdy prawie każdy radziecki pionier chciał sprawdzić na sobie, co czuła Kosmodemjańska, stojąc boso na śniegu, nie da się umieścić w jednym przypisie (pomijając to, że nie da się przypisu wykorzystać w spektaklu), więc pozostaje on poza świadomością odbiorcy polskiego.

Wiera uważała, że jest słaba, że przestraszyła się, że nie wytrzymała próby. Mąż uspokajał ją, przekonywał, że jest silna, że jest ambitna i że niepotrzebnie tak się przejmuje przygotowaniem do roli. Próbuje powiedzieć, że nawet podczas wojny ludzie nie tylko przeżywali strach, ale marzyli o miłości, potrafili też cieszyć się z prostych rzeczy, z „kwietniowego słońca”, na co Wiera odpowiada: „Я еще не напугалась так сильно, чтобы радоваться простому солнцу" (Rudkovskij 2016: 548).

W tłumaczeniu polskim zamiast prostego i dosłownego „nie przestraszyłam się" zostaje wykorzystany frazeologizm najeść się strachu o wyraźnie mocniejszym zabarwieniu emocjonalnym: „Widocznie nie najadłam się jeszcze strachu, żeby cieszyć się ze zwyczajnego słońca" (Rudkowski 2014: 115).

Aktorka nie przestaje szukać nowych możliwości, żeby przeżyć strach, odmawiając sobie prawa do jakichkolwiek pozytywnych emocji. Przygotowuje koktajl Mołotowa, rzuca butelką w opuszczony dom. Następnie każe koleżance wypróbować mieszankę wybuchową na ludziach. $Z$ dialogu wynika, że Wiera, rzucając butelkę, nie odczuła prawdziwego strachu, natomiast Katia się boi, jej strach prowadzi do postawienia sobie pytania: jak można zabić człowieka? Katia lęka się nie tylko o własne życie, lecz zastanawia się, czy ma prawo odebrać życie innej osobie, nawet jeśli to jest wróg.

Вера. Ой, я тебя умоляю. Это не так страшно.

Катя. Конечно, в нежилой дом не страшно. А вот в живого человека? Во врага? Как можно убить живого врага? Ты кого-нибудь убивала? (Rudkovskij 2016: 560).

W tłumaczeniu tego fragmentu emocja w kwestii wypowiedzianej przez Wierę znów traci podmiotowość, zaś w wypowiedzi Katii strach w ogóle przestaje być widoczny.

WIERA To nie takie straszne.

KATIA Jasne, w pusty dom - to nic takiego. Ale do człowieka?... Do wroga?... Jak można zabić żywego wroga? Zabiłaś już kogoś? (Rudkowski 2014: 128).

W kolejnych scenach sztuki przeżyć strach przypada Loszy, mężowi Wiery. Pewnego razu wraca z pracy do domu i widzi żonę w chustce: 
Лёша. Почему ты в платке?

Вера. У нас тиф. Постриглись наголо.

Лёша. Нет! Нет! Только не волосы. Нет! Только не твои чудесные волосы!

Лёша срывает с головы Веры платок. Все волосы на месте.

Лёша. Ё! Как ты меня напугала. (Плачет) (Rudkovskij 2016: 561).

LOSZA Czemu masz chustkę na głowie?

WIERA Panuje tyfus. Ostrzygłyśmy się na łyso.

LOSZA Nie! Nie! Tylko nie włosy! Nie! Tylko nie twoje cudowne włosy!

Losza zrywa chustę z głowy Wiery. Włosy jak były, tak są.

LOSZA No! Aleś mnie nastraszyła! (płacze) (Rudkowski 2014: 129).

Zauważmy, że w wypowiedziach Wiery strach najczęściej jest nazywany wprost, są to przede wszystkim rozmowy o strachu. Natomiast jej mąż nie tylko nazywa uczucie, lecz także naprawdę przeżywa strach i wyraża go tu i teraz za pomocą innych środków niż leksykalne.

Losza jest człowiekiem swojego czasu, jego strachy są bardzo zwyczajne: boi się, że może stracić to, co ma, uważa, że dzisiaj zdarzają się różne przykre rzeczy, które jest ciężko przeżyć. Wiera cały czas sprawdza męża, próbuje wybadać, czego boi się najbardziej. Następna rozmowa ma miejsce po tym, jak Wiera wynosi z domu wszystkie kosztowności i drogie ubrania.

Лёша. Какое у нас может быть будущее, если не будет одежды, денег, работы?

Вера. Потерять всё это так страшно?

Лёша. Страшно.

Вера. Неужели это страшнее войны? Не подходи. Что может быть всего этого страшнее? Ответь. Для меня это важно. Очень важно. (...)Что для тебя сегодня может быть очень страшным? Что? Что ты не сможешь пережить?

Лёша. Твою измену (Rudkovskij 2016: 562-563).

LOSZA Jaka przyszłość nas czeka, jeżeli nie mamy ubrań, pieniędzy, pracy?

WIERA Czy strata tego wszystkiego tak cię przeraża?

LOSZA Bardzo.

WIERA To bardziej przerażające niż wojna? [...] Co gorszego może być od tego wszystkiego? Odpowiedz, proszę. To dla mnie ważne. [...] Co dzisiaj najbardziej cię przeraża? Co? Co jest w stanie cię załamać?

LOSZA Twoja zdrada (Rudkowski 2014: 130-131).

Dalsze zachowanie Wiery wydaje się wręcz absurdalnie, ponieważ nie szuka już sposobów na osobiste przeżycie strachu, tylko postanawia wyleczyć z lęków męża. 
Nie zaprzestaje też poszukiwania odpowiedzi na pytanie, czego boi się współczesny człowiek, w rozmowie z kobietą w zoo wypytuje ją o lęki.

Вера. А вам не страшно, если начнется война?

Женщина. Нисколечко. И не начнется.

Вера. А что может быть страшно?

Женщина. Ну... страшно, если снизят еще больше зарплату, отправят в неоплачиваемый отпуск, сократят на работе... Или если я не выйду замуж... Или если моя мама умрет... Это страшно (Rudkovskij 2016: 567).

WIERA Nie boi się pani, że zacznie się wojna?

KOBIETA Ani troszkę. I nie zacznie się.

WIERA A co budzi pani lęk?

KOBIETA No... boję się, że obetną jeszcze bardziej pensje, że wyślą na bezpłatny urlop, zredukują etaty... Albo, że nie wyjdę za mąż... Albo, że moja mama umrze... Tego się boję (Rudkowski 2014: 135).

W oryginalnym tekście sztuki najczęściej spotykamy wyraz страшно, poprzez który w języku rosyjskim zwykle wyraża się uczucie strachu przed grożącym niebezpieczeństwem, niepokój. Najbliższym polskim odpowiednikiem jest osobowa forma czasownika bać się, ewentualnie obawiać się. Tłumaczka jednak nie zawsze sięga do tych wyrazów, często wykorzystuje kalkę strasznie (o czym była mowa wyżej). W tym przypadku wybiera jednak słowo lęk. Katarzyna Kuś, odwołując się do prac Wierzbickiej, pisze:

W wypadku jednak odmiennych, lecz sobie wzajemnie pokrewnych emocji, brak oczywistych i łatwo uchwytnych kryteriów pozwalających prawomocnie nazwać dane uczucie raczej jedną nazwą niż drugą, np. raczej lękiem niż strachem [...]. Tak więc istnienie dwóch różnych słów nie jest jeszcze gwarancją tego, że istnieją dwa dobrze odróżnialne od siebie rodzaje odczuć (Kuś 215-216).

$\mathrm{W}$ języku rosyjskim nie ma leksemu w pełni odpowiadającego polskiemu określeniu lęk, dlatego nie wprowadzamy w niniejszym artykule szczegółowego rozróżnienia pomiędzy wyrazami strach i lęk.

$\mathrm{Z}$ dialogu bohaterek wynika, że kobieta boi się niemal tego samego co Losza, Wiera jednak nie rezygnuje ze swojego zamiaru i chce wypróbować męża: odbywa na jego oczach stosunek seksualny z innym mężczyzną, dopytując się w trakcie, czy teraz mąż czuje strach? Losza, który odczuwał strach na samą myśl o zdradzie żony, w momencie, kiedy to wszystko zaczyna się dziać, odczuwa okropny ból i obrzydzenie. Ból jest taki silny, że Losza nie jest w stanie go wytrzymać i traci przytomność. 
Лёша. Это...Это...апокалипсис... Это ад... я в аду. Я на войне...

Вера. Тебе страшно?

Лёша. Хватит! Хватит! Перестаньте! Я не могу на это смотреть. Это мерзко!

Вера. [...] Тебе страшно?

Лёша. Это кошмар! Война - это смерть. Смерть. Перестаньте! Я же живой человек. Живой. Я же люблю тебя. Я не могу этого выдержать. Не могу! Это страшно. Я живой человек! Я живой...живой...живой... человек...

Лёша теряет сознание (Rudkovskij 2016: 570-571).

LOSZA To jest... To jakaś... apokalipsa... To piekło... jestem w piekle. Jestem na wojnie... WIERA Boisz się?

LOSZA Dość tego! Dość! Przestańcie! Nie moge na to patrzeć! To ohydne! WIERA [...] Boisz się?

LOSZA To jakiś koszmar! Wojna - to śmierć. Śmierć. Przestańcie! Jestem żywym człowiekiem. Żywym. Przecież cię kocham. Nie zniosę tego. Nie zniosę! To potworne! Jestem żywym człowiekiem! Żywym... żywym... żywym... człowiekiem...

Losza traci przytomność (Rudkowski 2014: 139).

Losza cały czas próbuje przekonać Wierę, że warto żyć i cieszyć się życiem, kochać i marzyć. Mówi, że współczesny człowiek ma swoje wyzwania, ale też nie powinien odmawiać sobie przyjemności. On chce naprawdę żyć tu i teraz, ona próbuje zrozumieć, w jaki sposób można było przeżyć wojnę.

Леша. Я жрать хочу! В мире кризис, я кручусь, как немецкая овчарка на работе, доходы падают, не могу поехать в отпуск, потому что везде свиной грипп. Вот что интересно современному человеку: как выжить сейчас?! Сейчас! Сейчас! И пожрать бы.

Вера. Вот! Вот. Давай вместе выживать. Вместе. Выживать (Rudkovskij 2016: 533).

LOSZA Chce mi się żreć! Na świecie triumfy święci kryzys, sprężam się, jak owczarek niemiecki w pracy, dochody lecą na łeb na szyję, nie mogę wyjechać na urlop, bo wszędzie panuje świńska grypa. Wiesz, co interesuje współczesnego człowieka - jak ma wyżyć w obecnych czasach?! Teraz! Teraz! I jak sobie podeżreć...

WIERA Dokładnie tak! Dokładnie! Spróbujmy razem powalczyć o życie... Razem... Przeżywać je... (Rudkowski 2014: 98-99).

Wiera i jej mąż dochodzą do porozumienia, kiedy zarówno wojna, jak i współczesny kryzys światowy nabierają wspólnych cech, stają się trudnym okresem, przez który bohaterowie muszą przejść razem i zostać przy życiu. Wiera wyłapuje z wypowiedzi Loszy słowo wyżyć, to ono ma połączyć i pogodzić małżonków. Wątek ten został rozmyty w tłumaczeniu, ponieważ zamiar wyżyć razem w trudnych 
warunkach, nie jest tym samym, co „razem przeżywać je [życie - N.R.]”, choć wersja z wykorzystaniem frazy razem powalczyć o życie zdaje się być bliższa intencji autora.

Sztuka kończy się teatralną premierą w Dzień Zwycięstwa. Wojna, pozostając jedynie tłem, pomogła autorowi bliżej przejrzeć się naturze współczesnego człowieka, pokazać jego lęki, a także wartości i przekonania, pomagające w walce o przetrwanie w dzisiejszym świecie. Strach przed śmiercią w czasie pokoju przekształca się i prowadzi do kreowania wiecznych i ogólnoludzkich wartości. W czasie wojny sprawia on, że na pierwszy plan wychodzą zachowania człowieka i jego cechy osobiste. Pokonanie strachu w czasie wojny rodzi odwagę, z którą dokonuje się czynów bohaterskich, w okresie pokojowym prowadzi do zwycięstwa nad sobą i doskonalenia ludzi (Oparina 31).

W zakończeniu warto dodać, że główny problem, z którym zetknął się utwór współczesnego dramatopisarza $\mathrm{w}$ rodzimym kręgu kulturowym, polegał na tym, iż o wojnie ojczyźnianej (według historiografii radzieckiej) przez długie lata mówiło się i pisało tylko na poważnie, tworząc wyłącznie pozytywny wizerunek radzieckiego bohatera. Dla narodów ZSSR to traumatyczne i bardzo bolesne doświadczenie historyczne oprócz swojej rzeczywistej tragiczności było przez pewien okres związane z wielkim zakłamaniem. Do dzisiaj nie powiedziano jeszcze o tej wojnie całej prawdy: ani w literaturze historycznej, ani w sztuce. $W$ czasach radzieckich $\mathrm{z}$ wielkim trudem trafiały do odbiorcy dzieła, pokazujące realne oblicze wojny, takie jak chociażby Wojna nie ma w sobie nic z kobiety, powieść białoruskiej noblistki z 2015 roku Swietłany Aleksijewicz. Twórcy niepochlebnych obrazów „świętej wojny" trafiali pod ostry ostrzał krytyki, oskarżano ich niemal o zdradę państwową.

W takiej sytuacji staje się oczywistym, że Rudkowski nie podtrzymuje panujących w społeczeństwie mitów i stereotypów związanych z wojną, świata sztuki Dożyć do premiery nie tworzy w oparciu o współczesny obraz świata, właściwy temu środowisku językowo-kulturowemu, do którego należy, lecz przedstawia własną wizję, bazując na osobistych przekonaniach, przeżyciach i emocjach. Dlatego w kręgu rosyjskojęzycznej kultury tekst sztuki wywołał dyskusję i otrzymał niejednoznaczną ocenę.

Napisana w 2009 roku sztuka Dożyć do premiery dostała drugą nagrodę (pierwsza nie została przyznana) w międzynarodowym konkursie dramaturgicznym „Badenweiler”, wyróżnienie w ogólnorosyjskim konkursie dramaturgii „Fakieł Pamiati”, organizowanego z okazji sześćdziesięciopięciolecia zwycięstwa, oraz specjalną nagrodę jury na pierwszym międzynarodowym festiwalu współczesnej dramaturgii „Rieabilitacija nastojaszcziego” (Erywań, Armenia). Warto jednak zaznaczyć, iż mimo powszechnego uznania komedia Rudkowskiego wywołała bardzo różne emocje. Związek działaczy teatralnych Rosji zakazał czytanie sztuki w Teatralnym Centrum „Na Strastnom”, gdzie miały być przedstawione utwory laureatów konkursu „Badenweiler”. 
Natomiast głównym problemem dla tłumacza była pewna niezgodność tzw. skryptu kulturowego. Utrwalony w kulturze polskiej obraz II wojny światowej mimo wspólnego doświadczenia historycznego narodów wyraźnie różni się od obrazu utrwalonego w rosyjskojęzycznym kręgu kulturowym. Napisany po rosyjsku utwór białoruskiego dramatopisarza, trafiając do odbiorcy na obszarze postsowieckim, jest próbą urozmaicenia odczuć w „przeżywaniu” wojny, sprzyja niewątpliwie transformacji emocjonalnej percepcji wojny. Trafiając do odbiorcy polskiego, komedia Rudkowskiego traci w dużej mierze swoją atrakcyjność, ponieważ nie odkrywa żadnych nowych możliwości w emocjonalnym oswojeniu tematu wojny. W tłumaczeniu na język polski traci się też kilka bardzo ważnych rzeczy: szablony i sztampy, charakterystyczne dla tekstów o wojnie, stereotypy wypracowane w języku sowieckiej propagandy. Oprócz tego niektóre ironiczne fragmenty nie zostały przetłumaczone w sposób właściwy, tracąc swój prowokacyjny często charakter, a jeszcze inne, związane $\mathrm{z}$ dobrze znanymi w kulturze rosyjskiej osobami oraz tekstami, pozostały zupełnie nieczytelne dla polskiego odbiorcy, chociażby takie jak postać Zoi Kosmodemjańskiej czy wykorzystane w tekście monologi ze sztuk Czechowa oraz cytaty ze znanych poetów rosyjskich i sowieckich.

\section{BIBLIOGRAFIA}

Krasavskij, Nikolaj A. „Ètimologičeskaâ harakteristika členov sinonimičeskogo râda „strah”, Grani poznaniâ 4 (14) (2011). Web. 12.09.2018. <http:/ / grani.vspu.ru/files/ publics/1325228786.pdf>

Kuś, Katarzyna. „Teoria emocji Anny Wierzbickiej”. Linguistica Copernicana 1(3) (2010). S. 207-224.

Małecki, Łukasz. „Definicja kognitywna jako narzędzie opisu emocji negatywnych w językach rosyjskim i ukraińskim : na przykładzie emocji strachu”, Acta Polono-Ruthenica 21 (2016). S. 39-49.

Oparina, Olga I. „Strah kak lingvo-psihologičeskaâ sostavlâûŝâ âzykovoj kartiny mira”, Âzyk, soznanie, kommunikaciâ. Vyp. 27. Red. V.V. Krasnyh, A.I. Izotov. Moskva: MAKS Press, 2004. S. 26-35.

Rudkowski, Nikołaj. „Dożyć do premiery”. Przeł. Bożena Majorczyk. Andriej Moskwin. Nowa dramaturgia białoruska. T. 2 Życie w pułapce. Warszawa: DUO SYSTEM, 2014. S. 90-143.

Rudkovskij, Nikolaj. „Dožit' do prem'ery”. Antologiâ sovremennoj belorusskoj dramaturgii. Red. T.F. Roslik. Minsk: Belaruskaja Èncyklapedyâ im. P. Broŭki, 2016. S. 525-575.

Wierzbicka, Anna. Jezyk - Umyst - Kultura. Red. J. Bartmiński. Warszawa: PWN, 1999. 
